Article

\title{
Extent of Soil Acidity in No-Tillage Systems in the Western Cape Province of South Africa
}

\author{
Adriaan Liebenberg ${ }^{1}$, John Richard (Ruan) van der Nest ${ }^{1}$, Ailsa G. Hardie ${ }^{2} \mathbb{}{ }^{\text {, }}$ \\ Johan Labuschagne ${ }^{3}$ and Pieter Andreas Swanepoel ${ }^{1, * \mathbb{C}}$ \\ 1 Department of Agronomy, Stellenbosch University, Stellenbosch 7602, South Africa; \\ 19192703@sun.ac.za (A.L.); 19009976@sun.ac.za (J.R.v.d.N.) \\ 2 Department of Soil Science, Stellenbosch University, Stellenbosch 7602, South Africa; aghardie@sun.ac.za \\ 3 Western Cape Department of Agriculture, Elsenburg 7606, South Africa; johanl@elsenburg.com \\ * Correspondence: pieterswanepoel@sun.ac.za
}

Received: 18 August 2020; Accepted: 24 September 2020; Published: 29 September 2020

\begin{abstract}
Roughly 90\% of farmers in the Western Cape Province of South Africa have converted to no-tillage systems to improve the efficiency of crop production. Implementation of no-tillage restricts the mixing of soil amendments, such as limestone, into soil. Stratification of nutrients and $\mathrm{pH}$ is expected. A soil survey was conducted to determine the extent and geographical spread of acid soils and $\mathrm{pH}$ stratification throughout the Western Cape. Soil samples $(n=653)$ were taken at three depths $(0-5,5-15,15-30 \mathrm{~cm})$ from no-tillage fields. Differential responses $(p \leq 0.05)$ between the two regions (Swartland and southern Cape), as well as soil depth, and annual rainfall influenced $(p \leq 0.05)$ exchangeable acidity, $\mathrm{Ca}$ and $\mathrm{Mg}, \mathrm{pH}_{(\mathrm{KCl})}$, and acid saturation. A large portion $(19.3 \%)$ of soils (specifically in the Swartland region) had at least one depth increment with $\mathrm{pH}_{(\mathrm{KCl})} \leq 5.0$, which is suboptimal for wheat (Triticum aestivum), barley (Hordeum vulgare), and canola (Brassica napus). Acid saturation in the 5-15 cm depth increment in the Swartland was above the $8 \%$ threshold for production of most crops. Acid soils are a significant threat to crop production in the region and needs tactical agronomic intervention (e.g. strategic tillage) to ensure sustainability.
\end{abstract}

Keywords: acid saturation; exchangeable acidity; calcium; magnesium; dolomitic lime; calcitic lime; wheat; barley; canola

\section{Introduction}

Conservation agriculture (CA) is an effective strategy to improve the efficiency of production of crops [1]. No-tillage is an important part of CA, along with crop rotation and the maintenance of an organic soil cover. No-tillage entails disturbing less than $25 \%$ of the total cropped area or implementing soil disturbances that are less than $25 \mathrm{~cm}$ wide [2].

In the Western Cape Province of South Africa, roughly $90 \%$ of farmers have converted to no-tillage systems [3]. The implications of implementing no-tillage is that soil amendments, such as limestone (lime), cannot be mixed into the soil with tillage actions, as in the case of conventional agriculture. As soil has not been disturbed through tillage for several decades in this region, soil layers are expected to form with more nutrients skewed towards the soil surface, as well as $\mathrm{pH}$ stratification with increasing soil depth due to the relatively slow movement of lime [4]. Surface broadcast lime has been found to take up to a year to move only $5 \mathrm{~cm}$ down the soil profile of a loam soil that received $489 \mathrm{~mm}$ of rainfall [5], or five years to move $7.5 \mathrm{~cm}$ in a silty clay loam soil that received a mean annual rainfall of $739 \mathrm{~mm}$ over the five years [6]. In a study by [7], it was found that it took between two and four years for $1.5 \mathrm{t} \mathrm{ha}^{-1}$ of surface-applied lime to move to a depth of $10 \mathrm{~cm}$ in a clay loam soil that received $570 \mathrm{~mm}$ of rainfall. Acidity will thus only be neutralised to the depth that lime is able to move. 
The southern Cape and Swartland regions of the Western Cape Province produce a large proportion of the country's wheat (Triticum aestivum) $(>50 \%)$, barley (Hordeum vulgare) $(89 \%)$, and canola (Brassica napus) (100\%) under dryland conditions [8-10]. Wheat, barley, and canola are sensitive crops to acid soil conditions [11,12]. Soil acidification results in decreased solubility or displacement of crop nutrients such as $\mathrm{P}, \mathrm{Ca}, \mathrm{Mg}$, and $\mathrm{K}[13,14]$. More importantly, however, is that as the $\mathrm{pH}_{(\mathrm{KCl})}$ of the soil decreases below 4.5, heavy metals such as $\mathrm{Al}$ become more soluble [15]. Toxic levels of $\mathrm{Al}$ causes, inter alia, stunting of crop roots [16], thus limiting the uptake of water and nutrients and consequently crop growth and production. It also results in the displacement and subsequent leaching of essential basic cations from cation exchange sites. Soil acidity may be detrimental to microbial activity in soil, such as Rhizobium that are important for nitrogen fixation $[17,18]$ as well as bacteria that break down complex carbon structures and mineralise other nutrients [19,20]. Acid soil conditions are thus limiting for crop growth as well as soil biology. Failing to address acidity within the soil profile will have a negative influence on sustainability of crop production systems.

Currently little is known regarding the extent to which the soils in southern Cape and Swartland regions are acid, or the extent of the occurrence of soil $\mathrm{pH}$ stratification. A lack of knowledge regarding the state of soils in these production regions with regards to soil acidity restricts addressing this crop-growth limitation. Therefore, a soil-sampling survey was conducted, taking soil samples at $0-5$, 5-15 and 15-30 cm depths from fields that have been under no-tillage for at least eight years. The soil samples were taken at three depth increments with the purpose of identifying the change in soil acidity with depth, while identifying whether there is an association with other soil attributes and explanatory variables. Explanatory variables included region, soil texture, rainfall, and years since last liming. The final objective was thus to determine the extent and geographical spread of soil acidity and $\mathrm{pH}$ stratification throughout the southern Cape and Swartland production regions in the Western Cape Province of South Africa, as well as possible causes thereof.

\section{Results and Discussion}

Figure 1 shows the distribution of soil $\mathrm{pH}_{(\mathrm{KCl})}$ for samples from the Swartland and southern Cape regions of South Africa, as well as individually for each region. Farmers aim for a soil $\mathrm{pH}_{(\mathrm{KCl})}$ of 5.5, so a $\mathrm{pH}_{(\mathrm{KCl})}$ distribution where the majority of observations are around 5.5 is to be expected. More samples from the Swartland region had a $\mathrm{pH}_{(\mathrm{KCl})}$ lower than 5.0 than the southern Cape region.

The $\mathrm{pH}_{(\mathrm{KCl})}$ stratification trend observed in both areas (Table 1) showed a decrease (from $0-5$ to $5-15 \mathrm{~cm}$ ) followed by an increase (from 5-15 to $15-30 \mathrm{~cm}$ ) in $\mathrm{pH}_{(\mathrm{KCl})}$ with increasing depth. The increase in soil $\mathrm{pH}_{(\mathrm{KCl})}$ from the 5-15 to the $15-30 \mathrm{~cm}$ depth could be due to the $15-30 \mathrm{~cm}$ depth increment having the natural $\mathrm{pH}_{(\mathrm{KCl})}$ of that specific soil, which is related to base status of the parent material [21]. The differential depth effect between the southern Cape and Swartland could possibly be due to the acid saturation component of the effective cation exchange capacity (ECEC) of the Swartland soils being higher than that of the southern Cape soils. The parent material and physical attributes, such as texture, of the soils that differ between the Swartland and southern Cape regions may further account for the differences in $\mathrm{pH}_{(\mathrm{KCl})}$ and exchangeable acidity, since ECEC depends highly on the texture of a soil [22]. Soils containing more clay or organic matter will have a greater ECEC. These soils will thus have a greater capacity to hold basic cations leading to a greater buffering capacity against $\mathrm{pH}$ change compared to sandy soils with a lower ECEC [23]. However, following a factor analysis to reduce the number of variables and to detect structure in the relationships between soil chemical properties (Table 2), it was found that soil texture had no effect $(p>0.05)$ on $\mathrm{pH}_{(\mathrm{KCl})}$, exchangeable acidity and acid saturation (Factor 3 in Table 3). This result may be due to a disproportionate number of samples being from a sandy-loam texture class (Table 4 ). 

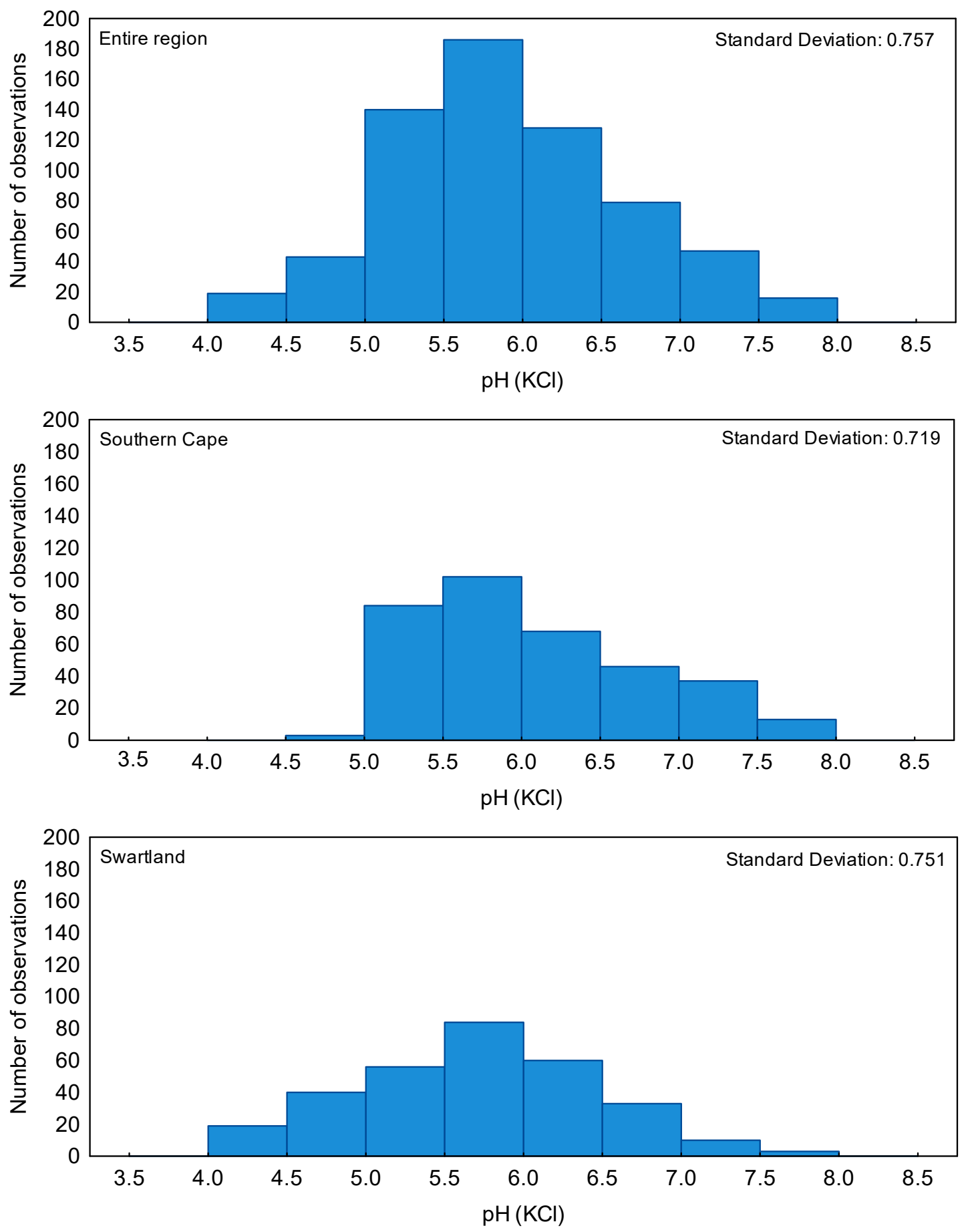

Figure 1. The mean soil $\mathrm{pH}_{(\mathrm{KCl})}$ distribution for all samples (top) as well for the southern Cape (middle) and the Swartland (bottom) regions separately. 
Table 1. Descriptive statistics of soil chemical attributes between three depths $(0-5,5-15$ and $15-30 \mathrm{~cm})$ for soils sampled in the southern Cape and Swartland regions. $\mathrm{SD}=$ standard deviation .

\begin{tabular}{|c|c|c|c|c|c|c|c|c|c|c|c|c|c|}
\hline & \multicolumn{2}{|c|}{$\mathbf{n}$} & \multicolumn{3}{|c|}{ Mean } & \multicolumn{2}{|c|}{ Median } & \multicolumn{2}{|c|}{ Minimum } & \multicolumn{2}{|c|}{ Maximum } & \multicolumn{2}{|c|}{ SD } \\
\hline & $\begin{array}{l}\text { Southern } \\
\text { Cape }\end{array}$ & Swart-Land & $\begin{array}{l}\text { Depth } \\
\text { (cm) }\end{array}$ & $\begin{array}{l}\text { Southern } \\
\text { Cape }\end{array}$ & Swart-Land & $\begin{array}{l}\text { Southern } \\
\text { Cape }\end{array}$ & Swartland & $\begin{array}{l}\text { Southern } \\
\text { Cape }\end{array}$ & Swart-Land & $\begin{array}{l}\text { Southern } \\
\text { Cape }\end{array}$ & Swart-Land & $\begin{array}{l}\text { Southern } \\
\text { Cape }\end{array}$ & Swart-Land \\
\hline \multirow{3}{*}{$\mathrm{pH}(\mathrm{KCl})$} & 118 & 99 & $0-5$ & 6.2 & 6.0 & 6.2 & 6.1 & 4.8 & 4.5 & 7.5 & 7.4 & 0.64 & 0.69 \\
\hline & 115 & 106 & 5-15 & 6.0 & 5.5 & 5.9 & 5.6 & 5.0 & 4.2 & 7.7 & 7.6 & 0.70 & 0.73 \\
\hline & 115 & 100 & $15-30$ & 6.2 & 5.8 & 5.8 & 5.7 & 5.1 & 4.1 & 7.9 & 7.9 & 0.87 & 0.76 \\
\hline \multirow{3}{*}{$\mathrm{Ca}\left(\mathrm{mg} \mathrm{kg}^{-1}\right)$} & 118 & 99 & $0-5$ & 2514 & 1728 & 1761 & 1390 & 430 & 344 & 12,898 & 10,134 & 2193 & 1473 \\
\hline & 115 & 106 & 5-15 & 1857 & 985 & 1127 & 763 & 366 & 116 & 9634 & 8562 & 1818 & 1007 \\
\hline & 115 & 100 & $15-30$ & 1818 & 658 & 889 & 545 & 326 & 106 & 11,644 & 3798 & 2339 & 550 \\
\hline \multirow{3}{*}{$\mathrm{Mg}\left(\mathrm{mg} \mathrm{kg}^{-1}\right)$} & 118 & 99 & $0-5$ & 241 & 255 & 206 & 218 & 46 & 53 & 679 & 888 & 116 & 150 \\
\hline & 115 & 106 & 5-15 & 201 & 141 & 173 & 119 & 41 & 18 & 481 & 408 & 99 & 81 \\
\hline & 115 & 100 & $15-30$ & 247 & 148 & 190 & 124 & 60 & 17 & 1463 & 720 & 182 & 107 \\
\hline \multirow{3}{*}{$\begin{array}{l}\text { Exchangeable acidity } \\
\left(\mathrm{cmol}_{\mathrm{C}} \mathrm{kg}^{-1}\right)\end{array}$} & 118 & 99 & $0-5$ & 0.13 & 0.18 & 0 & 0 & 0 & 0 & 1.30 & 1.39 & 0.33 & 0.40 \\
\hline & 115 & 106 & $5-15$ & 0.19 & 0.39 & 0 & 0 & 0 & 0 & 1.22 & 1.54 & 0.35 & 0.46 \\
\hline & 115 & 100 & $15-30$ & 0.12 & 0.24 & 0 & 0 & 0 & 0 & 1.00 & 1.12 & 0.28 & 0.36 \\
\hline \multirow{3}{*}{ Acid saturation (\%) } & 118 & 99 & $0-5$ & 1.49 & 2.64 & 0 & 0 & 0 & 0 & 15.53 & 23.00 & 3.78 & 5.88 \\
\hline & 115 & 106 & 5-15 & 2.72 & 8.17 & 0 & 0 & 0 & 0 & 17.44 & 44.16 & 5.07 & 10.38 \\
\hline & 115 & 100 & $15-30$ & 2.00 & 6.51 & 0 & 0 & 0 & 0 & 16.63 & 44.65 & 4.56 & 10.71 \\
\hline
\end{tabular}


Table 2. Principal component extraction using factor analysis. Varimax-normalised factor loadings for soil chemical properties across the Western Cape crop production region in South Africa are presented, along with the eigenvalue, total variance, and cumulative variance. Boldfaced values indicate the highest loading of each soil attribute, therefore forming part of a particular factor.

\begin{tabular}{|c|c|c|c|c|}
\hline Soil Chemical Properties & Factor 1 & Factor 2 & Factor 3 & Factor 4 \\
\hline $\mathrm{pH}_{(\mathrm{KCl})}$ & 0.465 & 0.073 & 0.747 & 0.060 \\
\hline Electrical resistance (Ohm) & -0.021 & -0.628 & -0.183 & -0.498 \\
\hline Electrical conductivity $\left(\mathrm{mS} \mathrm{m}^{-1}\right)$ & -0.036 & 0.787 & 0.072 & 0.433 \\
\hline Exchangeable acidity $\left(\mathrm{cmol}_{\mathrm{c}} \mathrm{kg}^{-1}\right)$ & -0.110 & -0.057 & -0.941 & -0.056 \\
\hline $\mathrm{Ca}\left(\mathrm{mg} \mathrm{kg}^{-1}\right)$ & 0.919 & -0.070 & 0.165 & 0.225 \\
\hline $\mathrm{Mg}\left(\mathrm{mg} \mathrm{kg}^{-1}\right)$ & 0.690 & 0.543 & 0.172 & -0.101 \\
\hline $\mathrm{Na}\left(\mathrm{mg} \mathrm{kg}^{-1}\right)$ & 0.052 & 0.829 & 0.0531 & -0.160 \\
\hline $\mathrm{K}\left(\mathrm{mg} \mathrm{kg}^{-1}\right)$ & 0.194 & 0.072 & 0.154 & 0.766 \\
\hline $\left.\mathrm{P}(\mathrm{mg} \mathrm{kg})^{-1}\right)$ & 0.131 & 0.009 & 0.009 & 0.719 \\
\hline Effective cation exchange capacity $\left(\mathrm{cmol}_{\mathrm{C}} \mathrm{kg}^{-1}\right)$ & 0.944 & 0.042 & 0.151 & 0.212 \\
\hline Acid saturation $(\%)$ & -0.126 & -0.172 & -0.916 & -0.146 \\
\hline Eigenvalue & 5.302 & 2.072 & 1.632 & 1.426 \\
\hline Total variance $(\%)$ & 40.8 & 15.9 & 12.6 & 10.7 \\
\hline Cumulative variance (\%) & 40.8 & 56.7 & 69.3 & 80.2 \\
\hline
\end{tabular}

Table 3. ANOVA F statistics and $P$-values for the fixed effects in the mixed models of soil of depths $(0-5,5-15$, and $15-30 \mathrm{~cm})$, region (Swartland vs. southern Cape), annual rainfall, soil texture, and years since previous liming. ECEC = Effective cation exchange capacity.

\begin{tabular}{|c|c|c|c|c|c|c|c|c|}
\hline \multirow{3}{*}{ Variables } & \multicolumn{2}{|c|}{ Factor 1} & \multicolumn{2}{|c|}{ Factor 2} & \multicolumn{2}{|c|}{ Factor 3} & \multicolumn{2}{|c|}{ Factor 4} \\
\hline & \multicolumn{2}{|c|}{$\mathrm{Ca}, \mathrm{Mg}, \mathrm{ECEC}$} & \multicolumn{2}{|c|}{$\begin{array}{c}\text { Electrical Resistance, } \\
\text { Conductivity, } \mathrm{Na}\end{array}$} & \multicolumn{2}{|c|}{$\begin{array}{c}\mathrm{pH}_{(\mathrm{KCl})} \text {, Exchangeable } \\
\text { Acidity, Acid Saturation }\end{array}$} & \multicolumn{2}{|c|}{$\mathbf{K}, \mathbf{P}$} \\
\hline & $F$ & $P$ & $F$ & $P$ & $F$ & $P$ & $F$ & $P$ \\
\hline Depth & 14.25 & $<0.001$ & 16.21 & $<0.001$ & 12.06 & $<0.001$ & 306.59 & $<0.001$ \\
\hline Region & 18.85 & $<0.001$ & 0.01 & 0.938 & 12.62 & 0.001 & 8.24 & 0.004 \\
\hline Rainfall & 3.32 & 0.001 & 0.39 & 0.924 & 6.33 & $<0.001$ & 3.43 & 0.001 \\
\hline Texture & 2.37 & 0.070 & 12.84 & $<0.001$ & 1.71 & 0.166 & 0.57 & 0.636 \\
\hline $\begin{array}{l}\text { Years since } \\
\text { liming }\end{array}$ & 0.92 & 0.500 & 0.73 & 0.667 & 0.98 & 0.451 & 1.69 & 0.103 \\
\hline
\end{tabular}

Table 4. Percentage of soil samples per texture class.

\begin{tabular}{cccc}
\hline Texture & All Samples & $\begin{array}{c}\text { Percentage of Samples } \\
\text { Southern Cape }\end{array}$ & Swartland \\
\hline Sandy loam & 89.13 & 92.55 & 85.20 \\
Sand & 9.04 & 7.45 & 10.86 \\
Sandy clay loam & 1.68 & 0 & 3.62 \\
Clay & 0.15 & 0 & 0.32 \\
\hline
\end{tabular}

Stratification could possibly be attributed to the higher $(p \leq 0.05)$ concentrations of basic cations found in the $15-30 \mathrm{~cm}$ depth increment compared to the $5-15 \mathrm{~cm}$ depth increment (Table 3 ). Basic cations can be leached downward through the soil profile and accumulate in the subsoil on top of impervious layers that prevent the complete loss of these cations. Clay particles tend to accumulate deeper in the soil profile, and the higher ECEC of these particles is able to hold more basic cations and therefore have a greater resistance to change in $\mathrm{pH}$ compared to the sandy soil in the shallow depth increments [24,25].

It is clear that the degree of $\mathrm{pH}$ stratification in the Swartland is more severe than in the southern Cape. A higher degree $(p \leq 0.05)$ of $\mathrm{pH}$ stratification was observed between the three respective soil depths of the Swartland soils, especially between the $0-5$ and 5-15 cm depths (Tables 1 and 3). Despite 
the abrupt change of $\mathrm{pH}_{(\mathrm{KCl})}$ from the topsoil to the subsoil, the subsoil $\mathrm{pH}_{(\mathrm{KCl})}$ was not lower than the optimal $\mathrm{pH}_{(\mathrm{KCl})}$ for most crops. According to the South African fertiliser guidelines, the optimal $\mathrm{pH}_{(\mathrm{KCl})}$ for wheat is 5.0, and for barley and canola 5.5 [26]. Other sources report an optimal $\mathrm{pH}_{\left(\mathrm{CaCl}_{2}\right)}$ of 5.5 for most crops $[27,28]$, which is equivalent to an approximate $\mathrm{pH}_{(\mathrm{KCl})}$ of 5.2 [29].

The mean $\mathrm{pH}_{(\mathrm{KCl})}$ of all three soil depths in the southern Cape was suitable to produce wheat, barley, and canola. A slight $\mathrm{pH}_{(\mathrm{KCl})}$ stratification was observed between the three soil depths of the soils sampled in the southern Cape, with the highest $\mathrm{pH}_{(\mathrm{KCl})}$ in the region being 7.9 and the lowest being 4.8 (Table 1). The mean $\mathrm{pH}_{(\mathrm{KCl})}$ of all three of the respective soil depths in the southern Cape were also optimal for wheat, barley, and canola production.

The trend observed for exchangeable acidity was as expected, when compared to the trend of $\mathrm{pH}_{(\mathrm{KCl})}$ over increasing depth. In both regions the 5-15 cm depth increment had higher $(p \leq 0.05)$ amounts of exchangeable acidity than the $0-5$ and $15-30 \mathrm{~cm}$ depth increments (Tables 1 and 3). It is as expected that the depth increment with the lowest $\mathrm{pH}_{(\mathrm{KCl})}$ also has the highest amount of exchangeable acidity. The mean exchangeable acidity in the 5-15 and 15-30 cm depth increments in the Swartland was more than double the amount in the same depth increments of the southern Cape. The maximum values of exchangeable acidity in the Swartland were higher in all three depth increments than the corresponding values of the southern Cape region. The difference in exchangeable acidity between the two regions may be ascribed to the higher $(p \leq 0.05)$ amounts of $\mathrm{Ca}$ in the southern Cape soils than the Swartland soils (Tables 1 and 3). This corresponds to findings that showed that increases $(p \leq 0.05)$ in the Ca content of soils correspond with decreases in the exchangeable acidity, specifically the $\mathrm{Al}$ component [30]. The relationship between high concentrations of $\mathrm{Ca}$ and lower amounts of exchangeable acidity in the soil may help to identify soils in other regions that are similarly managed, that may develop exchangeable acidity problems over time. This could especially be the case if the soils naturally contain low concentrations of $\mathrm{Ca}$.

A clear difference $(p \leq 0.05)$ in acid saturation for both regions was observed (Tables 1 and 3 ). The acid saturation for all three depths in the Swartland were higher $(p \leq 0.050$ than the corresponding depths in the southern Cape (Table 3). The mean acid-saturation percentages of both the 5-15 and the $15-30 \mathrm{~cm}$ depths in the Swartland were over three times the values of the corresponding depths in the southern Cape (Table 1). The mean value for the $5-15 \mathrm{~cm}$ soil depth in the Swartland was also above the $8 \%$ threshold given by [31], which is unfavourable for wheat production. The maximum acid saturation for all three depths of the Swartland soils were higher than the corresponding values in the southern Cape. The maximum acid saturation for all three depths in the Swartland were also above the $8 \%$ threshold value given for wheat. Furthermore, barley and canola are less tolerant to soil acidity than wheat, and therefore these acid saturation values in the Swartland may be even more restricting to these crops than to wheat [32-34].

The mean Ca concentrations in the Swartland soils (Table 1) were low for crop production in the top $0-15 \mathrm{~cm}$ of the soil profile and very low at the $15-30 \mathrm{~cm}$ depth when compared to the relative concentrations for crop production (Table 5). Furthermore, the minimum and maximum Ca concentrations reported in these soils were very low and very high respectively for crop production. The mean $\mathrm{Mg}$ concentration throughout the $0-30 \mathrm{~cm}$ of the soil profile in the Swartland soils were suitable for crop production. The minimum $\mathrm{Mg}$ concentrations ranged from low ( $0-5 \mathrm{~cm}$ depth) to very low (5-15 cm and 15-30 cm depth), while the maximum $\mathrm{Mg}$ concentrations reported were relatively high throughout the $0-30 \mathrm{~cm}$.

The mean Ca concentration in the $0-15 \mathrm{~cm}$ soil depth in the southern Cape soils was suitable for crop production in general (Table 5). However, the minimum Ca concentrations reported for the southern Cape soils were too low for crop production whilst the maximum concentrations ranged from high (15-30 cm depth) to very high (0-5 and 5-15 cm depth). The mean $\mathrm{Mg}$ concentrations in the southern Cape soils were suitable for crop production throughout the soil profile $(0-30 \mathrm{~cm})$. The minimum $\mathrm{Mg}$ concentrations were low at all three depth intervals and the maximum concentrations were high ( $0-5$ and $5-15 \mathrm{~cm}$ depth) to very high (15-30 cm depth). 
Both $\mathrm{Ca}$ and $\mathrm{Mg}$ are important macronutrients for plant growth and development, however different crops have varying requirements. Canola, for example, has twice the demand for Ca than wheat [35]. Furthermore, well-structured soils generally have more than twice as much Ca than $\mathrm{Mg}$ [36]. Both Ca and Mg play an important role in soil aggregate stability [37] and Ca helps maintain a nutrient balance within the soil [38]. Furthermore, Ca is essential for maintaining the structural integrity and expansion of cell walls and lipid membranes [39]. Calcium plays an important role in osmoregulation and internal signaling within the plant cells. Magnesium on the other hand forms part of the chlorophyll molecule and is thus essential in the photosynthetic processes within plants [37]. Magnesium also plays a role in the metabolism and movement of sugar in plants, which is essential for their growth and development.

The availability of nutrients such as $\mathrm{Ca}$ and $\mathrm{Mg}$ to plants is influenced by the soil $\mathrm{pH}$. As the soil $\mathrm{pH}$ decreases, the $\mathrm{H}^{+}$and $\mathrm{Al}^{3+}$ that become more soluble under these $\mathrm{pH}$ conditions displace basic cations such as $\mathrm{Ca}$ and $\mathrm{Mg}$ from the cation exchange sites on the soil particles, leading to the basic cations being leached down the soil profile where they are not available for plant uptake [14].

Table 5. Ca $\left(\mathrm{mg} \mathrm{kg}^{-1}\right)$ and $\mathrm{Mg}\left(\mathrm{mg} \mathrm{kg}^{-1}\right)$ concentrations in the soil for crop production [40].

\begin{tabular}{|c|c|c|}
\hline & Ca (mg kg $\left.{ }^{-1}\right)$ & $\operatorname{Mg}\left(\mathrm{mg} \mathrm{kg}{ }^{-1}\right)$ \\
\hline Very low & $<400$ & $<36$ \\
\hline Low & $400-1000$ & $36-120$ \\
\hline Moderate & $1000-2000$ & $120-360$ \\
\hline High & 2000-4000 & $360-960$ \\
\hline Very high & $>4000$ & $>960$ \\
\hline
\end{tabular}

The mean Ca concentration of the southern Cape soils was higher $(p \leq 0.05)$ for all three depth increments than the Ca concentrations of the Swartland soils, with the mean concentration in the 15-30 cm depth increment being nearly three times that of the Swartland soils (Tables 1 and 3). The higher $(p \leq 0.05)$ Ca concentrations reported in the southern Cape soil compared to the Swartland soils could be attributed to the soil parent material of the southern Cape being of a more calcareous nature [41]. Soils with a higher $\mathrm{pH}_{(\mathrm{KCl})}$ are expected to generally have a greater Ca concentration [35], which could also explain the higher $(p \leq 0.05)$ Ca concentration in the southern Cape soils compared to the Swartland soils, which had a lower mean $\mathrm{pH}_{(\mathrm{KCl})}($ Table 1). Although the criteria for sampling a field in the survey included no lime applications in the last year prior to sampling, relatively recent lime applications (1-3 years before sampling) could potentially explain the high Ca concentrations reported in the maximum values of both the Swartland and southern Cape Ca concentrations [42]. It was however found that there was no relationship $(p>0.05)$ between $\mathrm{Ca}$ and $\mathrm{Mg}$ concentrations in the soil and the number of years since the previous lime application was done (Table 3). The mean Mg concentrations did not show the same trend as Ca. The Swartland soils had higher $(p \leq 0.05)$ concentrations of $\mathrm{Mg}$ in the $0-5 \mathrm{~cm}$ depth increment and the southern Cape soils had higher concentrations in the $5-15$ as well as the 15-30 cm depth increment (Table 3). The addition of dolomitic lime on soils already high in $\mathrm{Mg}$ concentration could explain the high $\mathrm{Mg}$ concentrations reported in the maximum values of both regions' soils. Sandy textured soils with a low ECEC are more vulnerable to low Ca and $\mathrm{Mg}$ concentrations due to greater risk of being leached down the soil profile and could form part of the soils that were reported as having minimum $\mathrm{Ca}$ and $\mathrm{Mg}$ concentrations in both regions [37]. It was found that texture did not influence $(p \geq 0.05) \mathrm{Ca}$ and $\mathrm{Mg}$ concentrations in the soils (Table 3 ). As stated earlier, this result may be due to the disproportionate number of samples being in the same texture class and therefore an inaccurate correlation between soil texture and $\mathrm{Ca}$ and $\mathrm{Mg}$ concentrations could have been obtained (Table 4).

It was found that rainfall only influenced $(p \leq 0.05)$ Factor 1 (concentrations of both $\mathrm{Ca}$ and $\mathrm{Mg}$ as well as the CEC of soils) as such that increased rainfall was associated with increased loadings of Factor 1 (results not shown). Although higher annual rainfall could result in leaching of $\mathrm{Ca}$ and $\mathrm{Mg}$, 
higher rainfall can be associated with a higher CEC of soils as a result of a higher content of soil organic matter [37,39]. Rainfall did not influence $(p>0.05)$ Factor 3, which is linked to soil acidity aspects.

\subsection{Subset Data from Fields with $\mathrm{pH}_{(\mathrm{KCl})} \leq 5.0$ at Any Depth Increment}

Of the total number of samples taken at all three depths across the survey, $19.3 \%$ of the samples from the Swartland had a $\mathrm{pH}_{(\mathrm{KCl})} \leq 5.0$ and $6.2 \% \leq 4.5$ (Figure 1, Table 6). For the soils where at least one depth increment had a $\mathrm{pH}_{(\mathrm{KCl})} \leq 5.0$, the 5-15 $\mathrm{cm}$ depth had a $\mathrm{pH}_{(\mathrm{KCl})}$ that was lower $(p \leq 0.05)$ than the $0-5$ depth increment (Figure 2 ) and the exchangeable acidity (Table 7) was higher $(p \leq 0.05)$ than that of the $0-5 \mathrm{~cm}$ depth increment (Table 3). The $\mathrm{pH}_{(\mathrm{KCl})}$ and acidity of the $0-5$ and the $15-30 \mathrm{~cm}$ depth increments were more similar than the $0-5$ and 5-15 cm depth increments. The change in $\mathrm{pH}_{(\mathrm{KCl})}$ from the $0-5$ to the 5-15 cm depth increment is severe enough for the rooting depth to become limited, due to the $5-15 \mathrm{~cm}$ depth increment being below the threshold $\mathrm{pH}_{(\mathrm{KCl})}$ values for most crops [26].

Table 6. Percentage of samples per depth for each region with $\mathrm{pH}_{(\mathrm{KCl})} \leq 5.0$.

\begin{tabular}{lcc}
\hline \multicolumn{1}{c}{ Depth $(\mathbf{c m})$} & S. Cape $(\mathbf{\%})$ & Swartland (\%) \\
\hline $0-5$ & 0.00 & 11.11 \\
$5-15$ & 1.74 & 29.25 \\
$15-30$ & 0.87 & 17.00 \\
Total & 0.86 & 19.30 \\
\hline
\end{tabular}

Figure 2 showed that for the soils where at least one of the depth increments had $\mathrm{pH}_{(\mathrm{KCl})} \leq 5.0$, there was a decrease $(p \leq 0.05)$ in $\mathrm{pH}_{(\mathrm{KCl})}$ from the $0-5$ to the $5-15 \mathrm{~cm}$ depth increment. The $15-30 \mathrm{~cm}$ depth increment did not, however, differ $(p \leq 0.05)$ from the $0-5 \mathrm{~cm}$ depth increment. Soil $\mathrm{pH}_{(\mathrm{KCl})} \mathrm{of}$ below 5.0 is a growth limitation for barley, wheat, and canola [26]. The stratification shown in Figure 2 indicates that the change in soil $\mathrm{pH}_{(\mathrm{KCl})}$ is severe enough in these soils to possibly become a growth limitation to barley, wheat, and canola. The acid soil layer in a soil profile becomes a limitation for plant growth, ultimately decreasing the effective rooting depth. A decrease in the effective depth that roots can grow in a soil profile could impact crop production. In the study by Hirzel and Matus [43], it was reported that grain yield, plant height, and number of stems per meter of wheat were affected by the depth of the soil profile. In this study, grain yield was up to $37 \%$ higher in deep soils compared to shallow soils. Furthermore, there are various reports [44-47] stating that increases in effective soil depth for root growth improved the productivity and yield of maize (Zea mays L.), wheat, and barley. The positive effect of soil depth on crop productivity could be attributed to the increased ability of roots to take up nutrients and water at greater soil depths [48]. Whereas in shallow root systems, nutrients such as $\mathrm{N}$ can leach beyond the shallow root zone and be lost from the system [49]. 


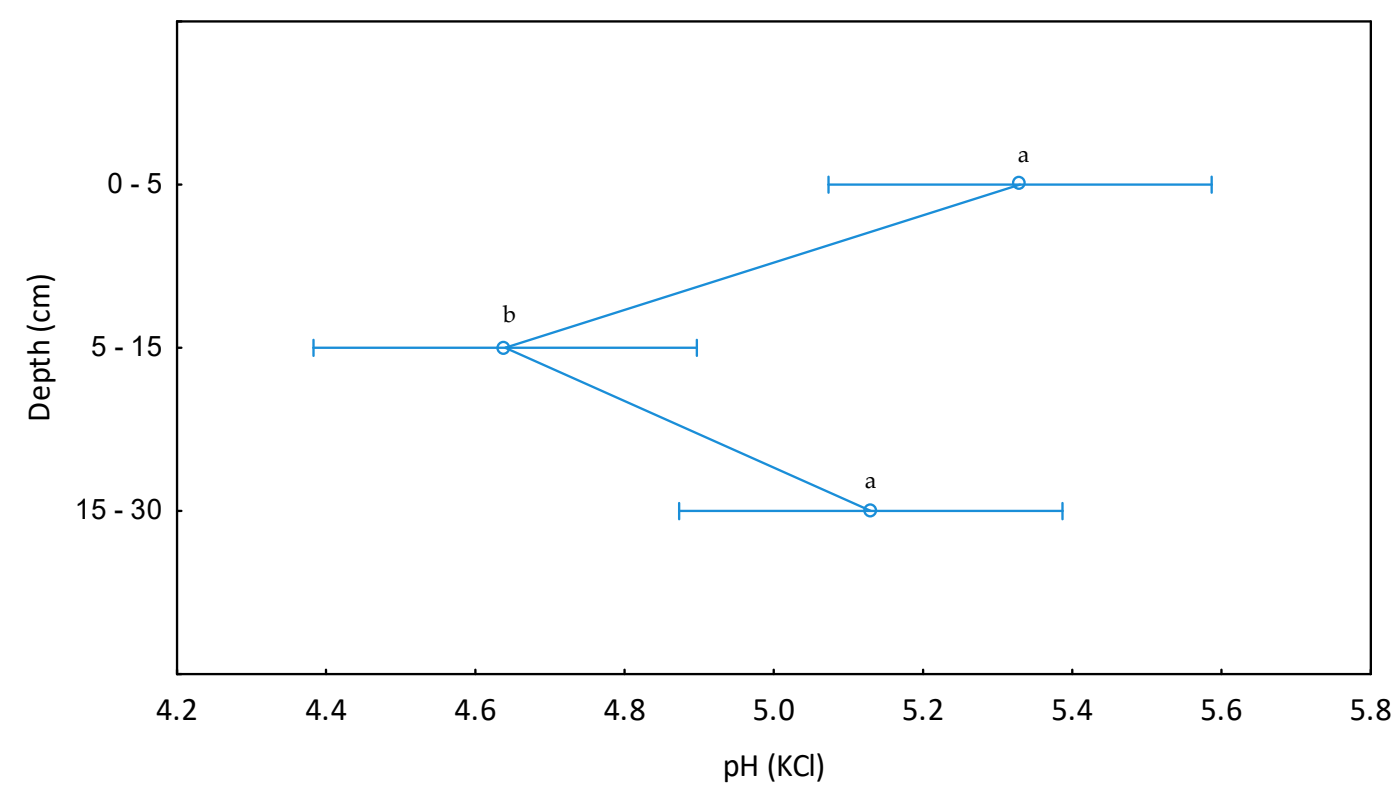

Figure 2. Stratification of $\mathrm{pH}_{(\mathrm{KCl})}$ between $0-5,5-15$, and 15-30 cm soil depth of soils with at least one depth increment with $\mathrm{pH}_{(\mathrm{KCl})} \leq 5.0$. No common superscript letter indicates a significant $(p \leq 0.05)$ difference.

The concentrations of $\mathrm{Ca}$ and $\mathrm{Mg}$ in the $0-5 \mathrm{~cm}$ depth increment were higher $(p \leq 0.05)$ than in both the 5-15 and 15-30 cm depth increments (Table 7). Stratification of nutrients such as $\mathrm{Ca}$ and $\mathrm{Mg}$ with increasing soil depth can be expected in long-term no-tillage soils $[31,50,51]$.

Table 7. F-and $p$ values of $\mathrm{pH}_{(\mathrm{KCl})}, \mathrm{Ca}\left(\mathrm{mg} \mathrm{kg}^{-1}\right), \mathrm{Mg}\left(\mathrm{mg} \mathrm{kg}^{-1}\right)$, exchangeable acidity $\left(\mathrm{cmolc} \mathrm{kg}^{-1}\right)$, and acid saturation (\%).

\begin{tabular}{lcc}
\hline & F Value & $p$ Value \\
\hline $\mathrm{pH}(\mathrm{KCl})$ & 7.76 & $<0.001$ \\
$\mathrm{Ca}\left(\mathrm{mg} \mathrm{kg}^{-1}\right)$ & 13.58 & $<0.001$ \\
$\mathrm{Mg}\left(\mathrm{mg} \mathrm{kg}^{-1}\right)$ & 6.88 & $<0.001$ \\
Exchangeable acidity (cmolc & 3.59 & 0.040 \\
$\mathrm{~kg}^{-1}$ ) & 6.13 & 0.040 \\
Acid saturation $(\%)$ & \\
\hline
\end{tabular}

Figures 3 and 4 indicate that the base status of the topsoil $(0-5 \mathrm{~cm})$ is higher $(p \leq 0.05)$ than that of the deeper depth (5-15 and 15-30 cm) increments (Table 8). Figures 3 and 4 indicate that the exchangeable acidity component of the effective cation exchange capacity (ECEC) of the 5-15 cm depth increment is much higher than the acidity component of the above or below depth increments. These trends in base status and exchangeable acidity correspond with Table 1, which indicates that the $\mathrm{pH}_{(\mathrm{KCl})}$ of the 5-15 cm depth increment was the lowest of the three sampling depths, since low $\mathrm{pH}_{(\mathrm{KCl})}$ corresponds with high levels of exchangeable acidity.

Table 8. Mean values of various soil measurements for the three depth increments. No common superscript letter indicates a significant $(p \leq 0.05)$ difference.

\begin{tabular}{lccc}
\hline $\begin{array}{c}\text { Soil Depth } \\
(\mathbf{c m})\end{array}$ & $\begin{array}{c}\text { Exchangeable } \\
\text { Ca }\left(\mathbf{m g ~ k g}^{-\mathbf{1}}\right)\end{array}$ & $\begin{array}{c}\text { Exchangeable } \\
\mathbf{M g}\left(\mathbf{m g ~ k g}^{-\mathbf{1}}\right)\end{array}$ & $\begin{array}{c}\text { Exchangeable Acidity } \\
\left(\mathbf{c m o l ~ k g}^{\mathbf{- 1}}\right)\end{array}$ \\
\hline $\mathbf{0 - 5}$ & $1039^{\mathrm{a}}$ & $188^{\mathrm{a}}$ & $0.68^{\mathrm{ab}}$ \\
$\mathbf{5 - 1 5}$ & $535^{\mathrm{b}}$ & $103^{\mathrm{b}}$ & $0.95^{\mathrm{a}}$ \\
$\mathbf{1 5 - 3 0}$ & $417^{\mathrm{b}}$ & $149^{\mathrm{b}}$ & $0.56^{\mathrm{b}}$ \\
\hline
\end{tabular}




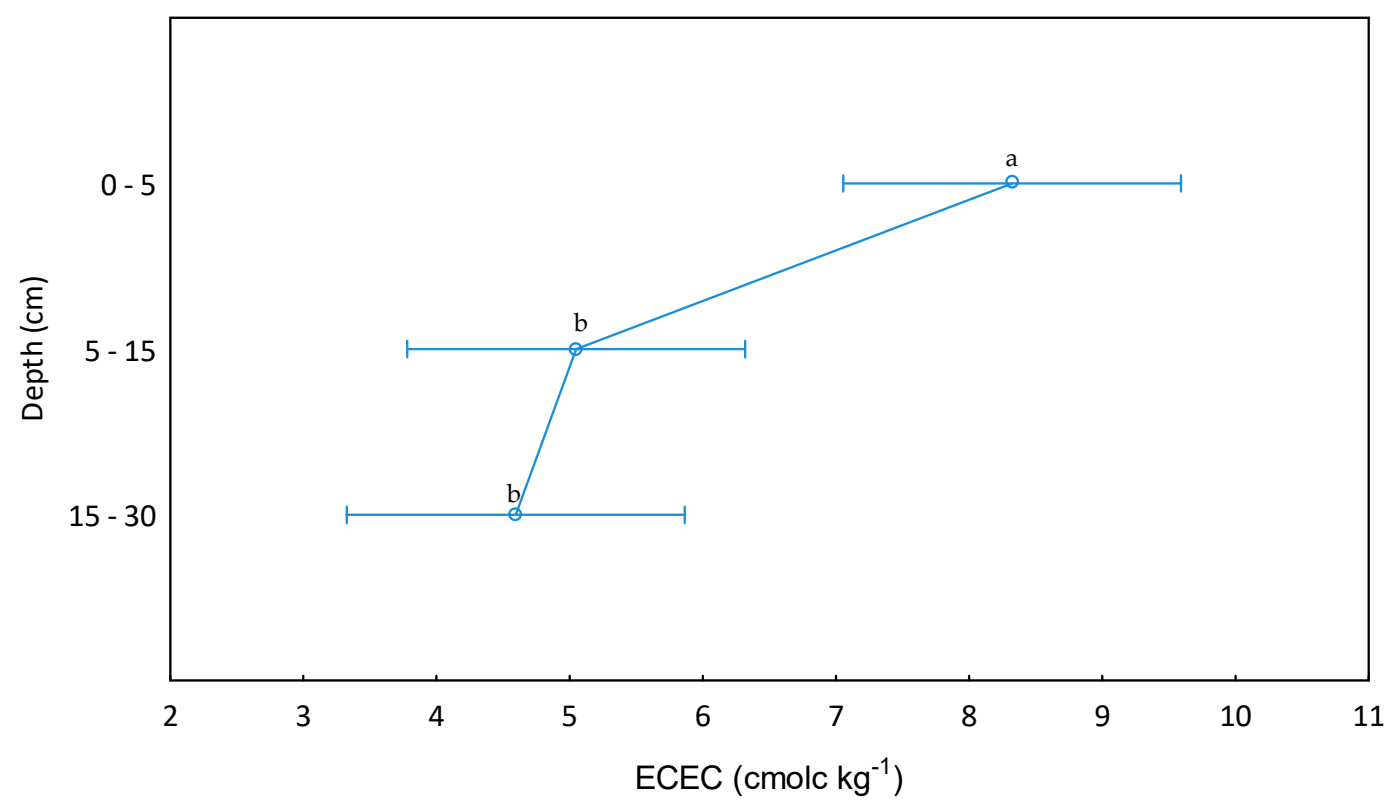

Figure 3. ECEC between 0-5, 5-15, and 15-30 cm soil depths of soils where at least one depth increment had $\mathrm{pH}_{(\mathrm{KCl})} \leq 5.0$. ECEC = Effective cation exchange capacity. No common superscript letter indicates a significant $(p \leq 0.05)$ difference.

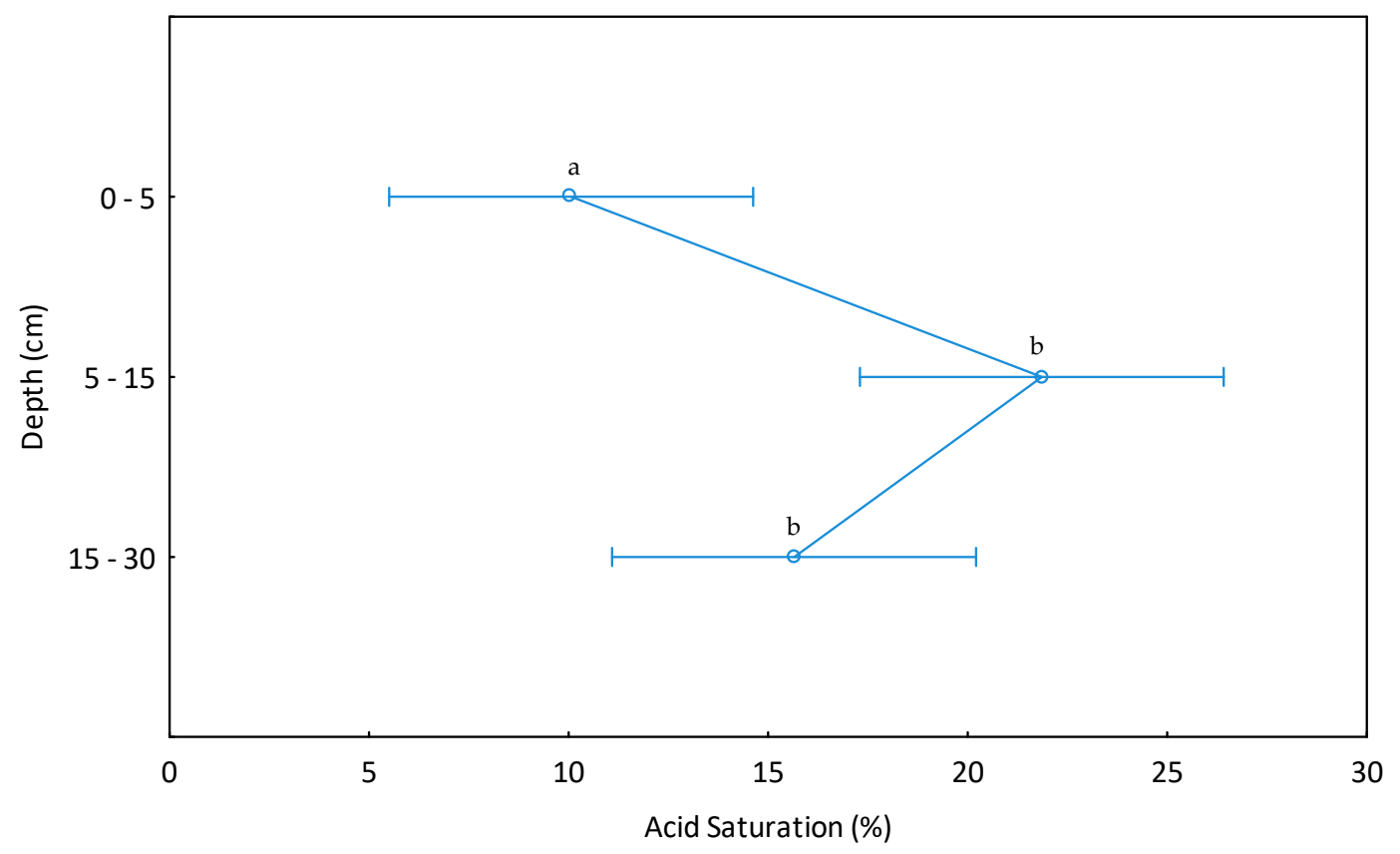

Figure 4. Stratification of acid saturation between $0-5,5-15$, and $15-30 \mathrm{~cm}$ soil depths of soils where at least one depth increment had $\mathrm{pH}_{(\mathrm{KCl})} \leq 5.0$. No common superscript letter indicates a significant $(p \leq 0.05)$ difference.

\subsection{Canola Leaf Nutrient Content}

Table 9 shows that of the 15 fields included in the survey where canola was cultivated, the leaf samples averaged above both the Canadian, South African, and USA threshold values for all the nutrients measured $[26,52,53]$. Some individual samples did, however, contain suboptimal amounts of $B$, even though the mean value is above the threshold values of the Canadian and USA standards, whilst also being within the range for the South African standard. It is standard practice for farmers 
who cultivate canola to apply leaf sprays in the growing season to apply B. The results from the leaf analyses that were done for this survey support this practice that farmers are already implementing.

Table 9. Sample means of analysed canola leaf nutrients in comparison with the Canadian, USA, and South African (RSA) threshold values for each nutrient. $n=15$; standard deviation is indicated in parenthesis.

\begin{tabular}{lccccccccccc}
\hline & $\begin{array}{c}\mathbf{N} \\
\mathbf{( \% )}\end{array}$ & $\begin{array}{c}\mathbf{P} \\
(\mathbf{\%})\end{array}$ & $\begin{array}{c}\mathbf{S} \\
(\mathbf{\%})\end{array}$ & $\begin{array}{c}\mathrm{Ca} \\
\mathbf{( \% )}\end{array}$ & $\begin{array}{c}\mathbf{M g} \\
\mathbf{( \% )}\end{array}$ & $\begin{array}{c}\mathbf{K} \\
\mathbf{( \% )}\end{array}$ & $\begin{array}{c}\mathbf{F e} \\
\mathbf{( m g} \\
\left.\mathbf{k g}^{-1}\right)\end{array}$ & $\begin{array}{c}\mathbf{C u} \\
(\mathbf{m g} \\
\mathbf{k g}^{-1}\end{array}$ & $\begin{array}{c}\mathbf{M n} \\
\mathbf{( m g} \\
\left.\mathbf{k g}^{-1}\right)\end{array}$ & $\begin{array}{c}\mathbf{Z n} \\
(\mathbf{m g} \\
\left.\mathbf{k g}^{-1}\right)\end{array}$ & $\begin{array}{c}\mathbf{B} \\
(\mathbf{m g} \\
\left.\mathbf{k g}^{-1}\right)\end{array}$ \\
\hline Sample Mean & $\mathbf{5 . 4 6}$ & $\mathbf{0 . 5 3}$ & $\mathbf{0 . 8 3}$ & $\mathbf{4 . 2 8}$ & $\mathbf{0 . 8 6}$ & $\mathbf{4 . 1 0}$ & $\mathbf{2 5 0 . 9 9}$ & $\mathbf{6 . 7 6}$ & $\mathbf{7 4 . 0 2}$ & $\mathbf{3 3 . 4 5}$ & $\mathbf{3 0 . 2 8}$ \\
& $\mathbf{( 0 . 6 2 )}$ & $\mathbf{( 0 . 1 1 )}$ & $\mathbf{( 0 . 1 0 )}$ & $\mathbf{( 1 . 2 4 )}$ & $\mathbf{( 0 . 3 8 )}$ & $\mathbf{( 2 . 1 0 )}$ & $\mathbf{( 1 8 5 . 2 8 )}$ & $\mathbf{( 5 . 5 5 )}$ & $(\mathbf{2 7 . 9 4 )}$ & $\mathbf{( 6 . 5 8 )}$ & $\mathbf{( 1 2 . 7 1 )}$ \\
\hline Canadian threshold [49] & 2.40 & 0.24 & 0.24 & 0.49 & 0.19 & 1.40 & 19.00 & 2.60 & 14.00 & 14.00 & 29.00 \\
USA threshold [50] & 3.60 & 0.37 & 0.47 & 1.60 & 0.10 & 2.15 & 82.00 & 4.00 & 20.00 & 28.00 & 20.00 \\
RSA threshold [23] & 3.50 & $0.3-0.6$ & 0.50 & $1.4-3.0$ & $0.2-0.6$ & 2.20 & $50-300$ & $3-5$ & $30-200$ & 20.00 & $20-50$ \\
\hline
\end{tabular}

\subsection{Recommendations}

Incorporating a one-off strategic tillage every few years in which surface-broadcast lime is incorporated into the soil profile could be a possible solution to the $\mathrm{pH}_{(\mathrm{KCl})}$ stratification (with an acid subsoil) that occurs in these long-term no-tillage soils. One-off strategic tillage in no-tillage systems has been found to be effective in alleviating nutrient stratification in the soil [54,55]. One-off tillage can thus be considered to redistribute the higher $\mathrm{Ca}$ and $\mathrm{Mg}$ concentrations that occur near the soil surface in both the Swartland and southern Cape soils. Furthermore, research done by [56-63] has shown that conducting a one-off tillage in soils that have been under no-tillage has no significant negative impact on soil physical and chemical attributes or on grain yield. It was reported by $[30,64-66]$ that incorporating lime into the soil (at varying depths, methods, and rates) was successful in alleviating subsoil acidity.

The relatively low Ca concentrations of the soils sampled in both the Swartland and southern Cape regions could be addressed through the addition of soil amendments such as gypsum $\left[\mathrm{Ca}\left(\mathrm{SO}_{4}\right)\right]$ or lime [35]. The application of gypsum can be considered on the soils with a suitable $\mathrm{pH}_{(\mathrm{KCl})}$ for crop production but a low concentration of $\mathrm{Ca}$. Gypsum which constitutes of about $22 \%$ Ca will allow for an increase in the Ca concentration of the soil without increasing the soil $\mathrm{pH}_{(\mathrm{KCl})}$ (due to its lack of carbonates), however it is more commonly used on sodic soils.

In the case of an acid soil, the addition of lime can be used to rectify soil acidity whilst addressing low $\mathrm{Ca}$ concentrations in the soil. Furthermore, in acid soils where the $\mathrm{Mg}$ concentration is low, as in the case of the minimum values reported for the $\mathrm{Mg}$ concentrations of both the Swartland and southern Cape soils, the application of dolomitic lime may be considered. The addition of dolomitic lime will enable soil acidity to be addressed as well as increasing the $\mathrm{Ca}$ and $\mathrm{Mg}$ concentrations in the soil.

\section{Materials and Methods}

\subsection{Description of Climate, Soil Types, and Land Use of the Survey Sites}

For the purpose of the survey, the Western Cape Province was separated into two regions according to differences in rainfall distribution and soil type, namely the southern Cape and Swartland regions (Figure 5). Both regions have a Mediterranean-type climate. The timing of rainfall differs between the two regions, with the majority (about $80 \%$ ) of the rainfall in the Swartland occurring from April to October, and the majority of the rainfall in the southern Cape (roughly $60 \%$ in the eastern districts and $75 \%$ in the western districts) occurring from April to October. The areas surrounding the following towns within the southern Cape region were sampled: Albertinia, Riversdale, Heidelberg, Witsand, Swellendam, Riviersonderend, Bredasdorp, Napier, Caledon, and Greyton. The annual mean rainfall for these areas ranged from $300-550 \mathrm{~mm}$ annually and the mean temperature is $17-18^{\circ} \mathrm{C}$ for all these areas. The areas surrounding the following towns were sampled in the Swartland: Malmesbury, 
Riebeeck-Kasteel, Gouda, Moorreesburg, Koringberg, Piketberg, and Porterville. The annual mean rainfall for these areas ranges from 300-600 mm and mean temperatures are $18-19{ }^{\circ} \mathrm{C}$.

The soils in both regions are classified as soils with minimal development, usually shallow and on hard or weathering rock, with or without intermittent diverse soils [67]. The soils in the Swartland are also red and yellow, massive or weak structured soils, with low-to-medium base status [67].

In terms of land use, similar crops are cultivated in both regions, due to both regions having Mediterranean-type climates. Both regions are mostly under dry-land wheat, barley, oats, canola, and lupin (Lupinus spp.) production. Various forage crops are incorporated into crop rotation systems to support livestock production. The preferred forage crops by southern Cape farmers generally include lucerne (Medicago sativa), whereas the Swartland farmers tend to cultivate annual Medicago spp. (mostly M. trancatula and M. polymorpha).

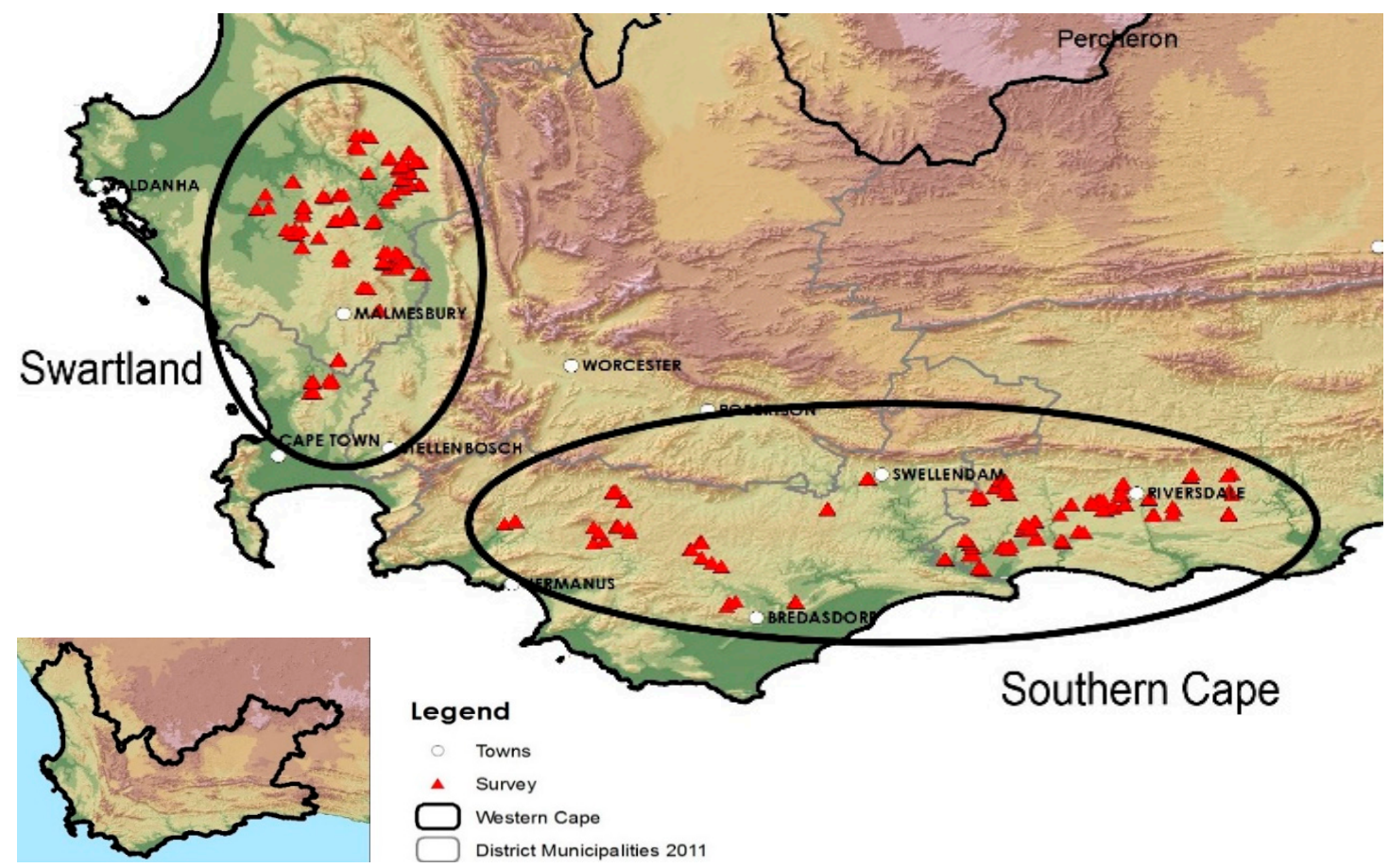

Figure 5. A map indicating the surveyed area, which included the southern Cape and Swartland regions of the Western Cape Province of South Africa.

\subsection{Sampling and Analyses}

The survey was conducted by means of soil samples accompanied by questionnaires relating to system management and liming history. The questionnaires were completed by each farmer who participated in the survey to obtain information regarding liming methods, liming history, and the crop history of the fields that were sampled.

For a respective field to be surveyed, the following criteria had to be met: (i) The field had to be managed under no-tillage for at least eight years prior to sampling for the survey; (ii) no liming should have been done on the respective fields in the current year of surveying (2019); (iii) the crop rotation system used by the farmer had to include either wheat, barley, or canola. Two hundred and fifty three fields were sampled across the Western Cape Province. At each field, six soil cores (5 cm diameter) were taken at depths of $0-5,5-15$, and $15-30 \mathrm{~cm}$ and composited per depth increment. Soil analyses included exchangeable base cations $(\mathrm{K}, \mathrm{Ca}, \mathrm{Mg}, \mathrm{Na})$, soil $\mathrm{pH}_{(\mathrm{KCl})}$, exchangeable acidity, and electrical resistance according to the methods described by [68]. Chemical analyses of $\mathrm{pH}$ were done in a 1:2.5 soil: $\mathrm{KCl}$ solution, and of exchangeable acidity and base cations with a potassium chloride and citric acid solution, respectively [68]. The standard procedures of [68] were used for the determination of cation-exchange capacity (CEC; ammonium acetate). Electrical resistance was determined by the 
method described by [69]. These soil chemical attributes were analysed at the three respective depths in order to determine the presence of nutrient or acidic stratification between the depth increments as well as to identify possible reasons for why acidity could be present in the soil.

In 15 of the fields where canola was planted in 2019, leaf samples were taken at physiological maturity to investigate relationships between soil nutrients, and nutrient uptake by crops. Leaf samples were taken of the youngest mature leaves shortly before flowering. Canola was chosen as the crop to analyse, since its requirement for various nutrients is higher than the other crops in the rotation systems. Calcium deficiencies are sometimes observed in the region on canola, but not for other crops (Personal communication, G.A. Agenbag, 2018). Therefore, if soil conditions are deteriorating due to acidification, canola would be the most likely crop in the system to show deficiencies first. The Ca concentrations in the leaves of the canola could thus be a further indication of the acid status of the soil.

\subsection{Data Analyses}

Descriptive statistics including mean, maximum, minimum, median, and standard deviation were calculated for samples for both the Swartland and southern Cape combined, as well as separately for the two regions. We used the standard deviation as an indicator of the variability of soil properties. Groups of correlated variables were defined for by using a factor analysis to reduce the number of variables and to detect structure in the relationships between soil chemical properties. Latent variables for each group of soil chemical properties were created by normalising (Varimax rotation) and averaging variables from each factor for which the eigenvalues of the correlation matrix were one or greater.

Analysis of variance for acid soil response variables and factor loadings were performed with mixed models incorporating the Kenward-Roger degrees-of-freedom method [70]. This method adjusts the estimator in computation of the Satterthwaite-type correction of the covariance matrix to account for heteroscedasticity. Soil depth was specified as the fixed effect and field as the replicated random effect. A Bonferroni post-hoc test was performed to compare soil parameter means across depths. Subsequently, fields with soil $\mathrm{pH}_{(\mathrm{KCl})}$ values lower than 5.5, the optimal threshold for most crops, were identified and separated into a subset for further analyses, and analysed using the Kenward-Roger method as described above. STATISTICA software version 13 was used to conduct the statistical analyses [71].

\section{Conclusions}

Although the mean $\mathrm{pH}_{(\mathrm{KCl})}$ across the entire surveyed area (Swartland and southern Cape) was of little concern in terms of crop production, a large portion (19.3\%) of soils (specifically in the Swartland) had at least one depth increment with $\mathrm{pH}_{(\mathrm{KCl})} \leq 5.0$, which is below the optimal values for barley, wheat, and canola production. Furthermore, a change $(p \leq 0.05)$ in soil acidity was observed over increasing depth, indicating stratification of acidity. It was also found that soil depth, annual rainfall of the region as well as the region itself, had an influence $(p \leq 0.05)$ on $\mathrm{Ca}, \mathrm{Mg}, \mathrm{pH}$, exchangeable acidity, and the acid saturation of the soil. The mean acid saturation in the $5-15 \mathrm{~cm}$ depth increment in the Swartland was above the $8 \%$ threshold value for wheat production. Due to barley and canola being less tolerant to soil acidity than wheat, however, these acid-saturation values may be more restricting to the production of these crops.

Of the fields that contained at least one depth increment with $\mathrm{pH} \leq 5$, higher amounts $(p \leq 0.05)$ of acidity were found in the $5-15 \mathrm{~cm}$ depth increment, where lime evidently was not able to neutralise acidity in no-tillage systems. Therefore, crop yield is expected to be negatively affected by acid soil conditions on $19.3 \%$ of Swartland soils. The significant stratification of soil acidity and Ca and $\mathrm{Mg}$ observed between soil layers needs to be addressed. Strategic one-off tillage may address the stratification of both soil acidity and nutrients, such as $\mathrm{Ca}$ and $\mathrm{Mg}$, and could therefore be considered as an option to incorporate into the management of no-tillage production systems. 
Author Contributions: Conceptualisation, P.A.S.; methodology, P.A.S., A.L., and J.R.v.d.N.; validation, all; formal analysis, A.L. and J.R.v.d.N.; investigation, A.L. and J.R.v.d.N.; resources, P.A.S. and J.L.; data curation, A.L., J.R.v.d.N. and P.A.S.; writing-original draft preparation, A.L. and J.R.v.d.N.; writing一review and editing, P.A.S., J.L., and A.G.H.; supervision, P.A.S., J.L., and A.G.H.; project administration, P.A.S.; funding acquisition, P.A.S. All authors have read and agreed to the published version of the manuscript.

Funding: This research was funded by Winter Cereal Trust, South Africa (WCT/B/2019/01).

Acknowledgments: This work was supported by the Winter Cereal Trust, South Africa (WCT/2019/01). We wish to thank J.A. Strauss and the Western Cape Department of Agriculture for the analysis of soil samples, assistance in identifying suitable farms to include in the survey, as well as L. MacKenzie for preparing the Figure 5. We thank D.G. Nel from the Centre for Statistical Consultation at Stellenbosch University for statistical analysis. We also thank the Protein Research Foundation for the bursary of A. Liebenberg and the South African Cultivar and Technology Agency (SACTA) and AB InBev for the bursaries of J.R. van der Nest.

Conflicts of Interest: The authors declare no conflict of interest. The funders had no role in the design of the study; in the collection, analyses, or interpretation of data; in the writing of the manuscript, or in the decision to publish the results.

\section{References}

1. Smith, H.J.; Kruger, E.; Knot, J.; Blignaut, J.N. Conservation Agriculture in South Africa: Lessons from case studies. CAB Int. 2017, 214-245.

2. FAO. Conservation Agriculture Principles; Food and Agriculture Organization of the United Nations: Rome, Italy, 2014; p. 1. Available online: http://faostat.fao.org/ (accessed on 18 September 2020).

3. Findlater, K.M.; Kandlikar, M.; Satterfield, T. Misunderstanding conservation agriculture: Challenges in promoting, monitoring and evaluating sustainable farming. Environ. Sci. Policy 2019, 100, 47-54. [CrossRef]

4. Barth, V.P.; Reardon, C.L.; Coffey, T.; Klein, A.M.; McFarland, C.; Huggins, D.R.; Sullivan, T.S. Stratification of soil chemical and microbial properties under no-till after liming. Appl. Soil. Ecol. 2018, 130, 169-177. [CrossRef]

5. Miller, L. How fast is lime moving and is it treating acidity at depth? South. Farming Syst. 2015, 8, 133-135.

6. Godsey, C.B.; Pierzynski, G.M.; Mengel, D.B.; Lamond, R.E. Management of soil acidity in no-till production systems through surface application of lime. Agron. J. 2007, 99, 764-772. [CrossRef]

7. Conyers, M.K.; Heenan, D.P.; McGhie, W.J.; Poile, G.P. Amelioration of acidity with time by limestone under contrasting tillage. Soil Tillage Res. 2003, 72, 85-94. [CrossRef]

8. $\quad$ USDA. Delayed Winter Rains Reduce South Africas 2015/2016 Wheat Prospects; United States Department of Agriculture: Washington, DC, USA, 2015; p. 1.

9. Mogala, M. A Profile of the South African Barley Market Value Chain; Department of Agriculture, Forestry and Fisheries: Pretoria, South Africa, 2017; pp. 1-20.

10. De Kock, J. Development Plan for Canola 2018; Protein Research Foundation: Rivonia, South Africa, 2018 ; p. 1.

11. Tang, C.; Rengel, Z.; Diatloff, E.; Gazey, C. Responses of wheat and barley to liming on a sandy soil with subsoil acidity. Field Crops Res. 2003, 80, 235-244. [CrossRef]

12. Angus, J.; Swan, T.; Kirkegaard, J.; Beven, A.; Duff, C.; Conyers, M. Canola and the Acid Throttle. Grains Res. Dev. Corp. Updates Pap. Available online: https://grdc.com.au/resources-and-publications/grdc-updatepapers/tab-content/grdc-update-papers/2008/06/canola-and-the-acid-throttle (accessed on 25 September 2020).

13. Foy, C.D.; Atkinson, D. Soil Chemical Factors Limiting Plant Root Growth. Adv. Soil Sci. 1991, $19,471$.

14. Kunhikrishnan, A.; Thangarajan, R.; Bolan, N.S.; Xu, Y.; Mandal, S.; Gleeson, D.B.; Naidu, R. Functional Relationships of Soil Acidification, Liming, and Greenhouse Gas Flux. Adv. Agron. 2016, 139, 1-71.

15. Kochian, K.V. Cellular mechanisms of aluminum toxicity and resistance in plants. Annu. Rev. Plant Physiol. Mol. Biol. 1995, 46, 237-260. [CrossRef]

16. Krstic, D.; Djalovic, I.; Nikezic, D.; Bjelic, D. Aluminium in Acid Soils: Chemistry, Toxicity and Impact on Maize Plants. Intech 2012, 13, 231-242.

17. Fageria, N.K.; Baligar, V.C. Plant nutrient efficiency: Towards the second paradigm. Braz. Soc. Soil Sci. 1999, 31, 183-204.

18. Rousk, J.; Bååth, E.; Brookes, P.C.; Lauber, C.L.; Lozupone, C.; Caporaso, J.G.; Fierer, N. Soil bacterial and fungal communities across a pH gradient in an arable soil. ISME J. 2010, 4, 1340-1351. [CrossRef] [PubMed] 
19. Robson, A.D.; Abbott, L.K. The effect of soil acidity on microbial activity in soils. Soil Acidity Plant Growth 1989, 4, 139-165.

20. Kunito, T.; Isomura, I.; Sumi, H.; Park, H.D.; Toda, H.; Otsuka, S.; Nagaoka, K.; Saeki, K.; Senoo, K. Aluminum and acidity suppress microbial activity and biomass in acidic forest soils. Soil Biol. Biochem. 2016, 97, $23-30$. [CrossRef]

21. Grieve, I.C. Effects of parent material on the chemical composition of soil drainage waters. Geoderma 1999, 90, 49-64. [CrossRef]

22. Fooladmand, H.R. Estimating cation exchange capacity using soil textural data and soil organic matter content: A case study for the south of Iran. Arch. Agron. Soil Sci. 2008, 54, 381-386. [CrossRef]

23. Nathan, M.V. Soils, Plant Nutrition and Nutrient Management. Univ. Mo. Ext. Available online: https://extension2.missouri.edu/mg4 (accessed on 25 September 2020).

24. Jacobsen, O.H.; Moldrup, P.; Larsen, C.; Konnerup, L.; Petersen, L.W. Particle transport in macropores of undisturbed soil columns. J. Hydrol. 1997, 196, 185-203. [CrossRef]

25. Sumner, M.E.; Miller, W.P. Cation exchange capacity and exchange coefficients. Methods Soil Anal. Part 3 Chem. Methods 1996, 5, 1201-1229.

26. FERTASA. Fertilization Handbook; Fertilizer Association of Southern Africa: Pretoria, South Africa, 2016; p. 224.

27. Gazey, C.; Davies, S. Soil Acidity: A Guide for WA Farmers and Consultants; Bulletin; Department of Agriculture and Food Western Australia: Perth, Australia, 2009; Volume 4784, pp. 1-52.

28. Miller, L. Acidity-Soil Sampling and Lime Incorporation under Review. Grain Res. Dev. Corp. Updates Pap. Available online: https:/grdc.com.au/resources-and-publications/grdc-update-papers/tab-content/ grdc-update-papers/2020/02/acidity-soil-sampling-and-lime-incorporation-under-review (accessed on 25 September 2020).

29. Van Lierop, W. Conversion of organic soil $\mathrm{pH}$ values measured in water, $0.01 \mathrm{M} \mathrm{CaCl} 2$ or $1 \mathrm{~N} \mathrm{KCl}$. Can. J. Soil Sci. 1981, 61, 577-579. [CrossRef]

30. Whitten, M.G.; Wong, M.T.F.; Rate, A.W. Amelioration of subsurface acidity in the south-west of Western Australia: Downward movement and mass balance of surface-incorporated lime after 2-15 years. Aust. J. Soil Res. 2000, 38, 711-728. [CrossRef]

31. Dang, Y.P.; Moodt, P.W.; Bell, M.J.; Seymour, N.P.; Dalal, R.C.; Freebairn, D.M.; Walker, S.R. Strategic-tillage in no-till farming systems in Australia's northern grains-growing region: II. Implications for agronomy, soil and environment. Soil Tillage Res. 2015, 152, 115-123. [CrossRef]

32. Foy, C.D. Tolerance of barley cultivars to an acid, aluminum-toxic subsoil related to mineral element concentrations in their shoots. J. Plant Nutr. 1996, 19, 1361-1380. [CrossRef]

33. DAFF. Production Guideline for Canola. In Production Guidelines; Department of Agriculture, Forestry \& Fisheries: Pretoria, South Africa, 2016; Volume 5, pp. 1-25.

34. DAFF. Production Guidelines for Wheat; Department of Agriculture, Forestry and Fisheries: Pretoria, South Africa, 2016; pp. 1-27.

35. Norton, R. Focus on Calcium: Its role in crop production. GRDC Updates Pap. Available online: https:/grdc.com.au/resources-and-publications/grdc-update-papers/tab-content/grdc-updatepapers/2013/02/focus-on-calcium-its-role-in-crop-production (accessed on 25 September 2020).

36. Botta, C. Understanding Your Soil Test Step by Step; Yea River Catchment Land-care Group: Yea, Australia, 2015; pp. 1-36.

37. Magdoff, F. Building soils for better crops: Organic matter management. Soil Sci. 1993, 156, 371. [CrossRef]

38. Parnes, R. Soil fertility: Chapter 14-Calcium and soil pH. Northeast. Org. Farming Assoc. Available online: https://www.nofa.org/soil/html/calcium.php (accessed on 25 September 2020).

39. Schlecht, E.; Buerkert, A.; Tielkes, E.; Bationo, A. A critical analysis of challenges and opportunities for soil fertility restoration in Sudano-Sahelian West Africa. Nutr. Cycl. Agroecosystems 2006, 76, 109-136. [CrossRef]

40. Hazelton, P.; Murphy, B. Interpreting Soil Test Results. In What Do all the Numbers Mean; CSIRO Publishing: Victoria, Australia, 2007.

41. White, P.J.; Holland, J.E. Calcium in Plant Physiology and Its Availability from the Soil; IFC: Colchester, UK, 2018; p. 2. 
42. Espinoza, L.; Slaton, N.A.; Mozaffari, M. Understanding the Numbers on Your Soil Test Report; Cooperative Extension Service; University of Arkansas, US Department of Agriculture, and County Government's Cooperating: Washington, DC, USA, 2006; pp. 1-4.

43. Hirzel, J.; Matus, I. Effect of soil depth and increasing fertilization rate on yield and its components of two durum wheat varieties. Chil. J. Agric. Res. 2013, 73, 55-59. [CrossRef]

44. Busscher, W.J.; Frederick, J.R.; Bauer, P.J. Effect of penetration resistance and timing of rain on grain yield of narrow-row corn in a coastal plain loamy sand. Soil Tillage Res. 2001, 63, 15-24. [CrossRef]

45. McDonald, C.K. Effect of soil properties on variation in growth, grain yield and nutrient concentration of wheat and barley. Aust. J. Exp. Agric. 2006, 46, 93-105. [CrossRef]

46. Christopher, J.T.; Manschadi, A.M.; Hammer, G.L.; Borrell, A.K. Developmental and physiological traits associated with high yield and stay-green phenotype in wheat. Aust. J. Agric. Res. 2008, 59, 354-364. [CrossRef]

47. Whitmore, A.P.; Whalley, W.R. Physical effects of soil drying on roots and crop growth. J. Exp. Bot. 2009, 60, 2845-2857. [CrossRef]

48. Richards, R. Genetic opportunities to improve cereal root systems for dryland agriculture. Plant Prod. Sci. 2008, 11, 12-16. [CrossRef]

49. Thorup-Kristensen, K. Effect of deep and shallow root systems on the dynamics of soil inorganic nitrogen during 3-year crop rotations. Plant Soil 2006, 288, 233-248. [CrossRef]

50. Ismail, L.; Blevins, R.L.; Frye, W.W. Long-term no-tillage effects on soil properties and continuous corn yields. Soil Sci. Soc. Am. J. 1994, 54, 193-198. [CrossRef]

51. Rahman, M.H.; Okubo, A.; Sugiyama, S.; Mayland, H.F. Physical, chemical and microbiological properties of an Andisol as related to land use and tillage practice. Soil Tillage Res. 2008, 101, 10-19. [CrossRef]

52. Canola Council of Canada. Identifying Fertilizer Requirements. 2017. Available online: https://www. canolacouncil.org/canola-encyclopedia/fertilizer-management/identifying-fertilizer-requirements/ (accessed on 18 September 2020).

53. Campbell, C. Reference Sufficiency Ranges for Plant Analysis in the Southern Region of the United States; North Carolina Department of Agriculture and Consumer Services Agronomic Division: Raleigh, NC, USA, 2000.

54. Kettler, T.A.; Lyon, D.J.; Doran, J.W.; Powers, W.L.; Stroup, W.W. Soil quality assesment after weed-control tillage in a no-till wheat fallow cropping system. Soil Sci. Soc. Am. J. 2000, 64, 339-346. [CrossRef]

55. Quincke, J.A.; Wortmann, C.S.; Mamo, M.; Franti, T.; Drijber, R.A. Occasional tillage of no-till systems: Carbon dioxide flux and changes in total and labile soil organic carbon. Agron. J. 2007, 99, 1158-1168. [CrossRef]

56. Quincke, J.A.; Wortmann, C.S.; Mamo, M.; Franti, T.; Drijber, R.A.; García, J.P. One-time tillage of no-till systems: Soil physical properties, phosphorus runoff, and crop yield. Agron. J. 2007, 99, 1104-1110. [CrossRef]

57. Baan, C.D.; Grevers, M.C.J.; Schoenau, J.J. Effects of a single cycle of tillage on long-term no-till prairie soils. Can. J. Soil Sci. 2009, 89, 521-530. [CrossRef]

58. Crawford, M.H.; Rincon-Florez, V.; Balzer, A.; Dang, Y.P.; Carvalhais, L.C.; Liu, H.; Schenk, P.M. Changes in the soil quality attributes of continuous no-till farming systems following a strategic tillage. Soil Res. 2015, 53, 263-273. [CrossRef]

59. Leygonie, I.R. The Effect of Once-Off Tillage on Selected Soil Physical and Chemical Properties and Resultant Crop Response on Shale Derived Soil under No-Tillage in the Swartland Sub-Region of the Western Cape; University of Stellenbosch: Stellenbosch, South Africa, 2016; pp. 1-117.

60. Liu, H.; Crawford, M.; Carvalhais, L.C.; Dang, Y.P.; Dennis, P.G.; Schenk, P.M. Strategic tillage on a Grey Vertosol after fifteen years of no-till management had no short-term impact on soil properties and agronomic productivity. Geoderma 2016, 267, 146-155. [CrossRef]

61. Van Zyl, J.G. Response of Wheat (Triticum Aestivum L.), Canola (Brassica Napus) and Medic (Medicago) To a Once-Off Mouldboard and Deep Tine Tillage in the Swartland Sub-Region of the Western Cape; University of Stellenbosch: Stellenbosch, South Africa, 2017; pp. 1-101.

62. Dang, Y.P.; Balzer, A.; Crawford, M.; Rincon-Florez, V.; Liu, H.; Melland, A.R.; Schenk, P. Strategic tillage in conservation agricultural systems of north-eastern australia: Why, where, when and how? Environ. Sci. Pollut. Res. 2018, 25, 1000-1015. [CrossRef] [PubMed] 
63. Conyers, M.; van der Rijt, V.; Oates, A.; Poile, G.; Kirkegaard, J.; Kirkby, C. The strategic use of minimum tillage within conservation agriculture in southern New South Wales, Australia. Soil Tillage Res. 2019, 193, 17-26. [CrossRef]

64. Caires, E.F.; Barth, G.; Garbuio, F.J. Lime application in the establishment of a no-till system for grain crop production in Southern Brazil. Soil Tillage Res. 2006, 89, 3-12. [CrossRef]

65. Caires, E.F.; Joris, H.A.W.; Churka, S. Long-term effects of lime and gypsum additions on no-till corn and soybean yield and soil chemical properties in southern Brazil. Soil Use Manag. 2011, 27, 45-53. [CrossRef]

66. Tiritan, C.S.; Büll, L.T.; Crusciol, C.A.C.; Carmeis Filho, A.C.A.; Fernandes, D.M.; Nascente, A.S. Tillage system and lime application in a tropical region: Soil chemical fertility and corn yield in succession to degraded pastures. Soil Tillage Res. 2016, 155, 437-447. [CrossRef]

67. Western Cape Department of Agriculture. CapeFarmMapper, ver. 2.3.1.1. Spatial Information \& Mapping Services. 2020. Available online: https://gis.elsenburg.com/apps/cfm/ (accessed on 18 September 2020).

68. Non-Affiliated Soil Analysis Work Committee. Handbook of Standard Soil Testing Methods for Advisory Purposes; Soil Science Society of South Africa: Pretoria, South Africa, 1990.

69. United States Salinity Laboratory Staff. Diagnosis and Improvement of Saline and Alkali Soils. In Agriculture Handbook no. 60; Department of Agriculture: Washington, DC, USA, 1954.

70. Kenward, M.G.; Roger, J.H. An improved approximation to the precision of fixed effects from restricted maximum likelihood. Comput. Stats Data Anal. 2009, 53, 2583-2595. [CrossRef]

71. TIBCO Software. Statistica (Data Analysis Software System), Version 13.5.0.17; TIBCO Software: Palo Alto, CA, USA, 2020.

(C) 2020 by the authors. Licensee MDPI, Basel, Switzerland. This article is an open access article distributed under the terms and conditions of the Creative Commons Attribution (CC BY) license (http://creativecommons.org/licenses/by/4.0/). 